Keywords:

Adventitious roots

coppicing

girdling, guanandi

partial girdling

vegetative rescue

Histórico:

Recebido 26/04/2016

Aceito $11 / 11 / 2016$

Palavras chave:

Anelamento

Decepa

Enraizamento adventício

Guanandi

Resgate vegetativo

Semianelamento

Correspondência: dagkratz@yahoo.com.br

\section{EPICORMIC SHOOTS INDUCTION AND ROOTING CUTTINGS OF Calophyllum brasiliense}

ABSTRAT: Calophyllum brasiliense is present in a wide natural distribution range in Brazil and its monopodial growth, with a rectilinear stem and a moderately dense timber has attracted the attention from the logging industry in recent decades. In the meantime, the lack of efficient rescue and vegetative propagation methods of adult plants has been a narrowing condition for the selection of superior genotypes in breeding programs of the species. Therefore, we evaluate epicormic shoots induction methods and the rooting cuttings of 14 year-old Calophyllum brasiliense trees. From this scope, three methods of epicormic shoots induction were evaluated: coppicing, girdling and partial girdling. We evaluate the number of produced sprouts and the percentage of sprouted trees at 06 , 12 and 15 months' after the experiment installation. Results have indicated the feasibility of Calophyllum brasiliense vegetative rescue by cuttings method using epicormic shoots induced by coppicing and girdling. In contrast, partial girdling was not effective in epicormic shoots emission. Concerning adventitious roots, the sprouting technique had no influence in the rooting of cuttings, showing variation among the different stock plants.

\section{INDUÇÃO DE BROTAÇÕES EPICÓRMICAS E ESTAQUIA DE Calophyllum brasiliense}

RESUMO: Calophyllum brasiliense apresenta ampla distribuição natural no Brasil e seu crescimento monopodial, fuste retilíneo e madeira moderadamente densa tem atraído o interesse da indústria madeireira nas últimas décadas. Entretanto, a carência em métodos eficientes de resgate e propagação vegetativa de material adulto tem sido um fator limitante na seleção de genótipos superiores em programas de melhoramento da espécie. Assim, objetivou-se avaliar métodos de indução de brotações epicórmicas e o enraizamento de estacas em árvores de Calophyllum brasiliense com 14 anos de idade. Para tanto, três métodos de indução de brotações epicórmicas foram implantados: decepa, anelamento e semianelamento. Avaliou-se o número de brotos produzidos e a porcentagem de matrizes brotadas aos 6, 12 e 15 meses após a instalação do experimento. Com as brotações resultantes, foram instalados três experimentos de estaquia, comparando o enraizamento adventício entre as diferentes matrizes e métodos de indução de brotações epicórmicas. Os resultados demonstraram a viabilidade do resgate vegetativo de Calophyllum brasiliense por estaquia utilizando brotações epicórmicas induzidas por decepa e anelamento do tronco. Em contrapartida, o semianelamento não foi eficiente na indução de brotações epicórmicas. Em relação ao enraizamento adventício, a técnica de indução não influenciou o enraizamento de estacas, apresentando variação entre as diferentes matrizes.

' Federal University of Mato Grosso - Cuiabá, Mato Grosso, Brazil

2 EMBRAPA - Colombo, Paraná, Brazil

${ }^{3}$ Federal University of Paraná - Curitiba, Paraná, Brazil 


\section{INTRODUCTION}

Calophyllum brasiliense Cambess (Calophyllaceae), popularly known as guanandi, is present in a wide natural distribution range in Brazil, occurring in floodplains of the Dense Ombrophilous Forest and Stationary Semideciduous Forest (CARVALHO, 2003; SOUZA et al., 2007). Widely used in shipbuilding in the 19th Century, it became the first hardwood established by the imperial government (SOUZA; LORENZI, 20I2).

Its considerable vigor and attractive silviculture features to the logging industry increased the focus on the species breeding (SOUZA et al., 2007; CIRIELLO; MORI, 20I5; CIRIELLO, 20I0). In this context, vegetative propagation is very important in improving the quality of forest plantations and the expansion of genetic gains (ROSADO et al., 2012; WENDLING et al., 2015).

Clonal forestry has generated significant advances in national and international timber production (ROSADO et al., 20I2). One of the challenges to overcome in clonal forestry is the aging effects of timber species, which are evidenced by means of physiological and biochemical alterations in mother plants (OSTERC; STAMPAR, 20II). One of the key consequences is the loss of rooting capacity (OSTERC; STAMPAR, 20II), root and vegetative vigor (WENDLING et al., 2015) which often limit the expansion of clonal forests.

The comprehension of the plant maturation process may increase the perspective in succeeding cloning of adult trees, bringing a greater efficiency for selection, improvement and above all, enhancement of clonal forestry (WENDLING et al., 2014). Several studies have mentioned the importance of using juvenile propagules in propagation of forest species (WENDLING et al., 20I3; PEREIRA et al., 20I5; STUEPP et al., 2015b).

Propagules rejuvenation or reinvigoration is commonly obtained by coppicing of adult plants (STUEPP et al., 20I4; RICKLI et al., 20I5). However, such method is highly dependent on the regrowth of mother plants capacity and, in certain cases, it turns to be unfeasible due to low vigor. In such cases, the use of techniques such as girdling and partial girdling are recommended, not damaging the plant survival (PEREIRA et al., 2015; DIAS et al., 2015; STUEPP et al., 20I5a).

Thus, given the importance of vegetative rescue and propagation of Calophyllum brasiliense adult plants, we evaluated the efficiency of coppicing, girdling and partial girdling techniques for epicormic shoots induction and the effect of mother trees on rooting cuttings and root vigor.

\section{MATERIAL AND METHODS}

\section{Epicormic shoots induction}

The experiment was established on October 2010, in Adrianópolis, Paraná State, Brazil. The regional climate is mesothermal-humid subtropical, with hot summers and typical concentration of rainfall (average temperature above $22^{\circ} \mathrm{C}$ ) and winter with no frequent frosts (average temperature below $18^{\circ} \mathrm{C}$ ), with no dry season settled. The soil of the region is classified as Typic Udorthents, Eutrophic, with wavy terrain with slopes between $20 \%$ and $45 \%$ (SANTOS et al., 2006).

We selected 30 trees from a 14-year-old experimental plantation of Calophyllum brasiliense, planted in spacing $3 \times 2 \mathrm{~m}$. The selected trees had diameter at breast height $(\mathrm{DBH})$ average of $20.56 \mathrm{~cm}$ and average height of $13.37 \mathrm{~m}$. Three epicormic shoots induction techniques were evaluated: coppicing, girdling and partial girdling, using ten plants per treatment. The girdling was performed by removing a ring with about $1.0 \mathrm{~cm}$ wide, without damaging the timber and the coppicing consisted in cutting of the tree. Partial girdling consisted in removing $50 \%$ of the stem circumference. Both girdling and partial girdling were executed at $30 \mathrm{~cm}$ above the ground.

In April and October of 2011 and January of 2012 (i.e. at 06,12 and 15 months after experiment installation, respectively) we evaluate the average number of cuttings obtained per sprouted mother plant (NE) and the percentage of sprouted mother plants (MB). The experiment was conducted as a full-randomized design with three treatments and ten replications.

We attest the homogeneity of variance with Bartlett's test $(p<0.05)$ followed by variance analysis $(p<0.01$ and $p<0.05)$ and the test $(p<0.01$ and $p<0.05)$ for comparison between Ist and 2 nd collections. As per 3rd collection there was not any statistical analysis performed, once $100 \%$ of the girdled mother plants did not produced any sprouts.

\section{Adventitious rooting of cuttings}

Experiments related to rooting cuttings were installed in April and October of 20II and January of 2012 to evaluate rooting of epicormic shoots obtained from coppicing, girdling and partial girdling from different Calophyllum brasiliense mother plants.

Cuttings were prepared with $8 \pm 1 \mathrm{~cm}$ of length with two leaves submitted to $50 \%$ reduction from original surface. Cuttings were sterilized with a $2.5 \%$ sodium hypochlorite solution for 5 minutes (bactericidal 
function) and then washed in running water for 5 minutes. Afterwards, the base of all cuttings was treated with fungicide $5 \%$ for 5 minutes (systemic function). Finally, cuttings bases were treated with indole-3-butyric acid (IBA) at a 6,000 $\mathrm{mg} \cdot \mathrm{L}^{-1}$.

Rooting was carried out in $110 \mathrm{~cm}^{3}$ tubes, filled with vermiculite and carbonized rice bark ( $1: 1$ $\mathrm{v} / \mathrm{v}$ ), in about $2 \mathrm{~cm}$ deep, placed in a greenhouse with temperature monitored by thermostat (Figure I) and nebulization irrigation, with relative humidity (over than $80 \%$ ) automatically controlled by a humidistat.

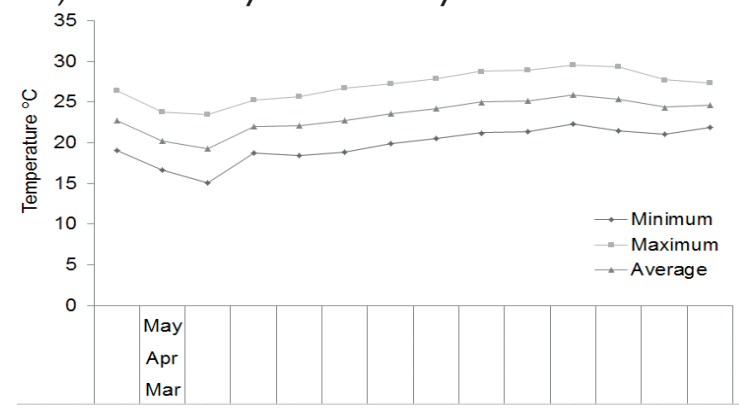

FIGURE I Maximum, medium and minimum greenhouse average temperatures between April 20II and May 2012. Source: Laboratory of Forest Species Propagation of Embrapa Florestas, Colombo, Paraná State, Brazil.

As 150 days elapsed, cuttings were transferred to the shade house $(50 \%$ of shade and micro sprinkler irrigation, with nine daily irrigations, on a ratio of Iminute timeframe and I44 L.h.-1 flow rate) for 30 days. Cutting were then transferred to an area of direct sunlight (micro sprinkler irrigation, with four daily irrigations, on a ratio of 30 - minutes timeframe and $97 \mathrm{~L} \cdot \mathrm{h}^{-1}$ flow rate) for 30 days to induce rustification.

As a result of a reduced range of epicormic shoots emission in certain mother plants, we chose to use only those that produced more than 32 cuttings per collection. Thus, the experiments I, II and III had six, four and four mother plants, respectively. The experiment was conducted as a full-randomized design basis with four replications, with a minimum of eight cuttings per unit.

When exiting the greenhouse (I50 days) we evaluated cuttings survival (SSCV), number of roots (NR), largest root length (CMR) and total root length (CTR); when exiting the shade house (I80 days) we evaluated survival (SSCS) and, at the end of the experimental period (210 days), the rooting percentage into direct sunlight (EAPS).

The data were analyzed with an analysis of variance (ANOVA), the treatment variances were evaluated for homogeneity with the Bartlett's test, and the variables with significant differences in the $F$ test had their means compared with the Tukey test at $5 \%$ probability.

\section{RESULTS AND DISCUSSION}

\section{Epicormic shoots induction}

We verified a higher percentage of sprouted plants as a result of coppicing and girdling, in first and second collections $(\mu=95 \%)$. The highest ranges, irrespective from the collection periods were observed in coppicing. The partial girdling showed to be ineffective for epicormic shoots induction, showing the lowest values for such variable (Table I).

Regarding shoots sprouting, we observed significant differences in the first and second collections, highlighting the superiority of coppicing compared to partial girdling in the first and to the girdling and partial girdling in the second collection. The results also suggest a gradual reduction in the epicormic shoots emission in girdled mother plants and conversely, an increase in the epicormic shoots in partial girdled ones (Table I).

The epicormic shoots induction has been associated to several factors, in which, environmental as a response to sunlight on the dormant buds (MEIER et al., 20I2), physiological and hormonal, as a result of stresses (BOND; MIDGLEY, 2003; BURROWS, 2008) or even considering, moderated genetic variations among plants (MEIER et al., 20I2). The largest epicormic shoots emission in plants under coppicing can be the result of sunlight incidence on the base of these plants in comparison to the other methods, once explained by onsite auxin photo oxidation (GORDON et al., 2006), consequently catalyzing the breakdown dormancy of the buds from the base of Calophyllum brasiliense stems.

The hormonal imbalance at the base of stems surpasses auxin inhibition (MEIER et al., 20I2), as well as the presence of sunlight is not considered as the only one responsible for epicormic shoots induction (NICOLINI et al., 200I). The growth activation of dormant buds have their regulation by genetic and hormonal signals (MEIER et al., 2012), as attested in association with an imbalance between auxins and cytokinins. Then, the photosynthetic production beneath the affected area is a consequence of blockade auxin conduction (WAN et al., 2006), jointly with the increase of cytokinin concentrations transmitted by the root, leading to germination of dormant buds (RASMUSSEN et al., 20I0).

The coppicing and girdling techniques have been effective in breaking the relation between auxins and cytokinins, as used in practice to justify epicormic shoots induction in several tree species (SANTIN et al., 2008; DIAS et al., 20I5; RICKLI et al., 20I5). Among these, coppicing has shown greater efficacy in terms of vegetative 
TABLE I Average cuttings productivity per mother plant (CP) and percentage of sprouted stock plants (SSP) at six (Ist collection) ten ( 2 nd collection) and fourteen months timeframe (3rd collection) by means of different Calophyllum brasiliense epicormic shoots induction methods.

\begin{tabular}{|c|c|c|c|c|c|c|}
\hline \multirow{3}{*}{ Vegetative rescue method } & \multicolumn{2}{|c|}{ Ist collection } & \multicolumn{2}{|c|}{ 2nd collection } & \multicolumn{2}{|c|}{ 3rd collection } \\
\hline & $\mathrm{CPI}$ & SSP & $\mathrm{CP} 2$ & SSP & $\mathrm{CP3}$ & SSP \\
\hline & C stock plant ${ }^{-1}$ & $\%$ & C stock plant ${ }^{-1}$ & $\%$ & C stock plant ${ }^{-1}$ & $\%$ \\
\hline Coppicing & $22.5 a$ & $100.0 \mathrm{a}$ & $28.6 \mathrm{a}$ & $70.0 \mathrm{a}$ & 43.8 & 50.0 \\
\hline Girdling & 13.4ab & $90.0 \mathrm{a}$ & $6.8 \mathrm{~b}$ & $60.0 \mathrm{a}$ & 0.0 & 0.0 \\
\hline Partial girdling & $6.0 \mathrm{~b}$ & $30.0 \mathrm{~b}$ & 2.0 & 10.0 & 11.0 & 10.0 \\
\hline
\end{tabular}
and girdling treatments; 3 Statistical test was not carried out due to the small frame of replications. Averages followed by the same letter in the column do not differ from each other, upon $t$ test at $5 \%$ error probability.

rescue in Ilex paraguariensis (WENDLING et al., 2013; STUEPP et al., 20I5a; 2016), Araucaria angustifolia (WENDLING et al., 2009), Anadenanthera macrocarpa (DIAS et al., 20I5) and Toona ciliata (PEREIRA et al., 20I5).

Several studies have been attesting evidences in which sprouting of lateral shoots after removal of the apex may be a result of sugar mobilization, in associating to hormones serving as a marker in the process (MASON et al., 20I4; VAN DEN ENDE, 20I4). According to such theory, the epicormic shoots induction only occurs with the availability of an adequate amount of carbohydrates in order to meet the later stages of these shoots sprouting (VAN DEN ENDE, 20I4. In the present study, the loss of apical dominance did not seem to occur with girdled and partial girdled plants. Therefore reducing the accumulation of sugars in the sectioned area and consequently in the sprouting percentage.

Thus, the reduced shoots sprouting and the percentage of these plants when applying the girdling technique happens to restrain the purpose of Calophyllum brasiliense vegetative rescue (Table I). The low efficiency of partial girdling in epicormic shoots induction was also observed in Toona ciliata plants. On the other hand, the cuttings produced from the above mentioned technique had evidenced a high rooting cuttings percentage (PEREIRA et al., 20I5).

The difficulty of girdling in plants without directly reaching the cambium had proved to be a limitation to the correct application of the technique. The damage to the region area generates a tumescence just above the girdle (Figure 2E), result from the onsite accumulation of soluble sugars and starch, along with the cessation of stem growth below the girdle (CHANO et al., 20I5), in some cases, resulting the death of the plant (BOND; MIDGLEY, 2003) (Figure 2C and D). It is common the intense deepening of the cut, bypassing the cambium and reaching the xylem, reducing the hydraulic conductivity and the translocation of photoassimilates (GLEASON et al., 2016).
Similarly, the stress generated by the girdling technique may invert the translocation direction, transforming the drains in sources and influencing the conduction of photo assimilates to the region below the cut (MEl et al., 20I5). It is noteworthy that girdling may causes serious and permanent damage to the girdled plants (BOND; MIDGLEY, 2003; MEl et al., 20I5), as noted in this study (Figure $2 \mathrm{C}$ and $\mathrm{D}$ ).
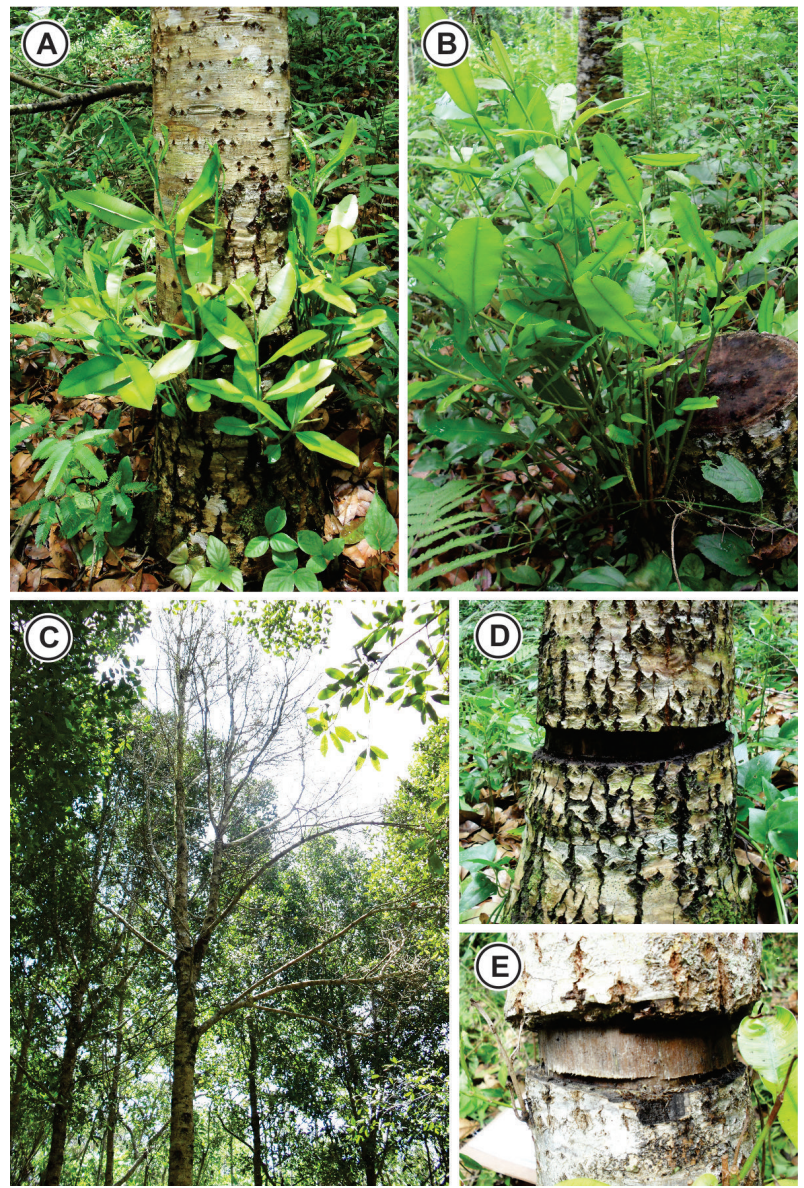

FIGURE 2 General features of epicormic shoots techniques through girdling (A) and coppicing (B); dead girdled plant (C); girdled plant without emission of epicormic shoots (D); stem tumescence just above the girdling 15 months after its implementation (E). 
On the other hand, the proper application of the girdling technique may trigger partial or complete healing of the wound, justifying its use in vegetative rescue avoiding mortality of plants (SANTIN et al., 2008). Yet, based on the proposed objective of genetic material vegetative rescue, with subsequent mass spread by means of other more efficient techniques for forest plants propagation, such as minicutting (OLIVEIRA et al., 20I2).

Girdling technique resulted in sprouts from only one collection period for rooting purposes after six months, differently from coppicing, which in most plants, leveraged the productivity by at least two collections
(Figure 3). The sprouts availability for rooting in two or more collections suggests a higher certainty to achieve the objective of the proposed vegetative rescue, mainly given the great influence of environmental conditions in connection with different seasons in the rooting of cuttings (FRAGOSO et al., 20I5).

\section{Adventitious rooting of cuttings}

All cuttings from epicormic shoots presented adventitious rooting, implying the feasibility of coppicing and girdling for Calophyllum brasiliense propagules reinvigoration (Figure 3).
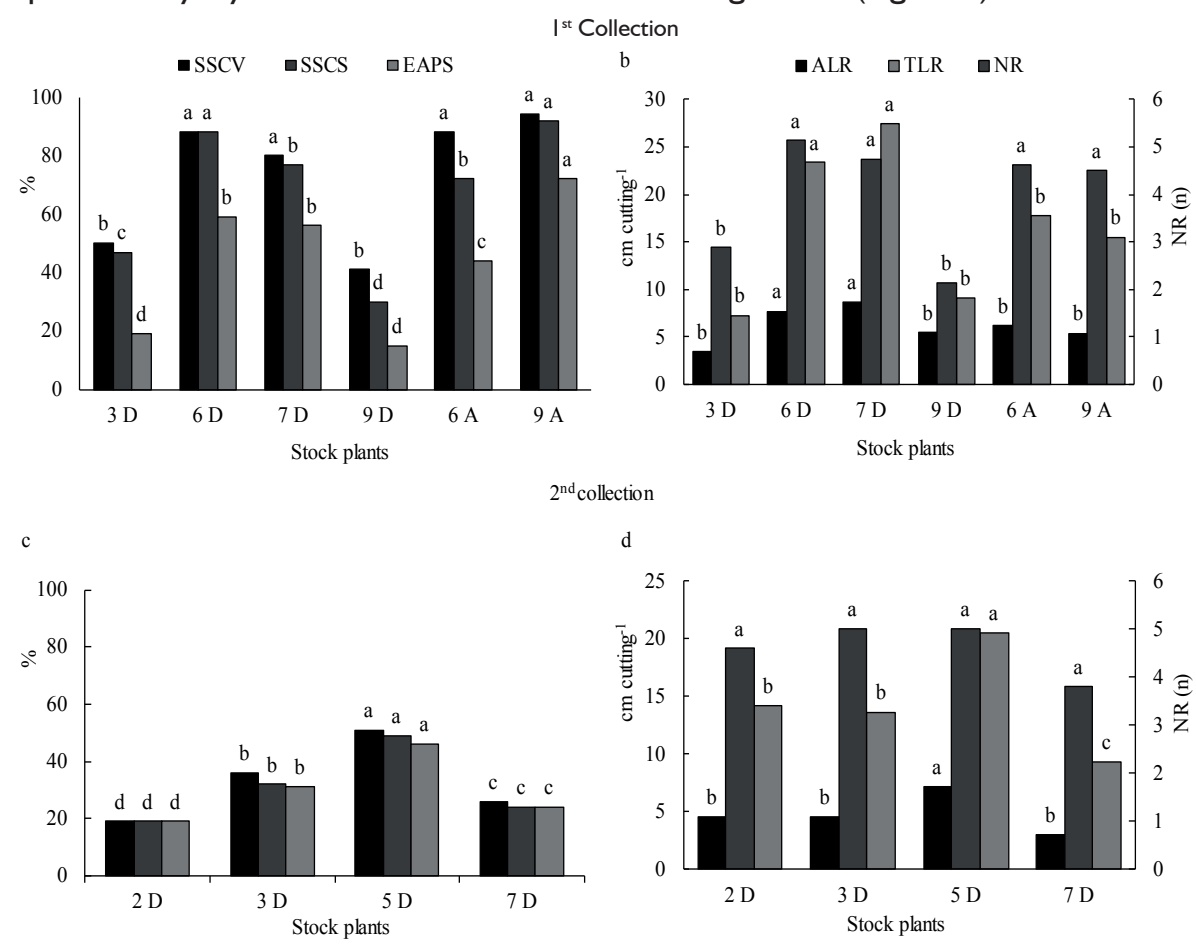

$3^{\text {rd }}$ collection
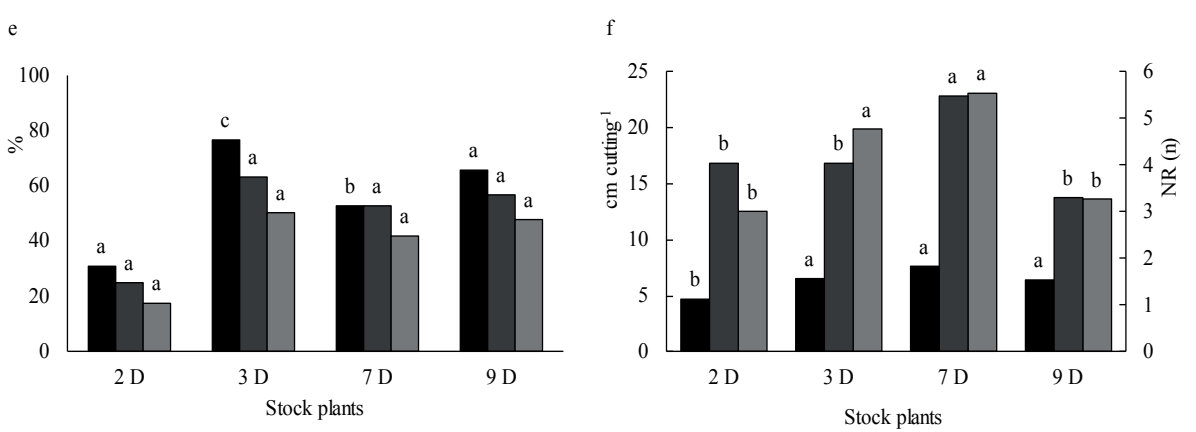

FIGURE 3 Survival at greenhouse exit (SEGH), shade house exit (SESH) and adventitious rooting in full sunlight (RFS) (A, C, E); the largest root length (ALR), total root length (TLR) and number of roots (NR) (B, D, F) in Calophyllum brasiliense cuttings from different stock plants and epicormic shoots induction techniques. Where $D$ - trees under coppicing and A - girdled trees, collected at 06, 12 and 15 months after the application of techniques. Averages followed by the same letter between the stock plants do not differ from each other, upon $t$ test at $5 \%$ error probability. 
The highest survival percentages when exiting the greenhouse were observed with cutting from the first collection (six months after the application of techniques), comprising fall and winter (Figure 3B); with cutting from the second collection in spring and summer and with cuttings from the third collection in summer and fall seasons (Figure 3D and F). Nevertheless, it is noteworthy that differently from the rootings phase the shoots development happened in the spring/summer/fall, fall/winter and spring/summer for collection in I, 2 and 3, respectively.

The environment temperature may affect the increase of endogenous levels of certain metabolites and hormones essential to rooting, as it influences the increase of metabolism and cell division in plants (RASMUSSEN et al., 2015). The effects of higher temperatures onsite are evident in this study in the first and third collections with development of shoots under the influence of spring/ summer/fall and spring/summer, seasons respectively, resulting in higher percentage in relation to the second collection (Figure 3). In general, there was variation between stock plants in all of the analyzed variables (Figure 3).

Several studies have evaluated the effect of different genotypes in the adventitious rooting of plant propagules (OLIVEIRA et al., 20 I2; PEREIRA et al., 20 I 5). Additionally, in Calophyllum brasiliense species, it was observed a high genetic variability regarding progenies and clones on cuttings rooting (CIRIELLO, 20I0).

It is important to highlight that only stock plants number 3 and 7, from coppicing, had shown enough sprouts production and were installed for rooting purposes in the three collections (Figure 3). Similarly, only on the first collection, we could compare stock plants under coppicing and girdling, where in general, there was no effect of epicormic shoots induction technique upon rooting of cuttings (Figure 3 ).

The reduced cuttings mortality after exiting of greenhouse (I 50 days) suggests the frame adopted for rooting structure maintenance of cuttings was adequate (Table 2). The adequate determination for the optimal propagules maintenance timeframe in the greenhouse has been emphasized in the literature (REIS et al., 2008), especially in terms of adequate rooting, therefore, enabling a higher perspective for cuttings survival in subsequent phases (OLIVEIRA et al., 20I2).

\section{CONCLUSIONS}

Girdling and coppicing techniques were effective in obtaining Calophyllum brasiliense basal epicormic shoots. There was a wide variation in adventitious rooting among clones/stock plants. Propagules from Calophyllum brasiliense epicormic sprouts endure good potential for adventitious rooting.

\section{ACKNOWLEDGMENTS}

This research was supported by the Brazilian Agricultural Research Corporation (Embrapa Florestas). To Berneck S.A. for the availability of genetic material and cooperation in the research.

\section{REFERENCES}

BOND W. J.; MIDGLEY J. J. The evolutionary ecology of sprouting in woody plants. International Journal of Plant Sciences, v. I64, p. I03-I|4, 2003.

BURROWS, G.E. Syncarpia and Tristaniopsis (Myrtaceae) possess specialised fire-resistant epicormic structures. Australian Journal of Botany, v. 56, p. 254-264, 2008.

CARVALHO, P. E. R. Espécies arbóreas brasileiras. Brasília: Embrapa Informação Tecnológica; Colombo: Embrapa Florestas. 2003. $1039 \mathrm{p}$.

CHANO, V.; LÓPEZ, R.; PITA, P.; COLLADA, C.; SOTO, A. Proliferation of axial parenchymatic xylem cells is a key step in wound closure of girdled stems in Pinus canariensis. BMC Plant Biology, v. I5, p. I-64, 2015.

CIRIELLO, E. Variabilidade genética de caracteres relacionados ao enraizamento de estacas de progênies e clones de guanandi (Calophyllum brasiliense Cambess.). (Dissertação). Botucatu: Faculdade de Ciências Agronômicas, Universidade Estadual Paulista "Julio De Mesquita Filho"; 2010.

CIRIELLO, E.; MORI, E. S. Rooting of guanadi (Calophyllum brasiliense CAMBESS) cutting using indole-butyric acid. Cerne, v. 2I, n. 4, p. 64I-648, 2015.

DIAS, P. C.; XAVIER, A.; OLIVEIRA, L. S.; FÉLIX, G. A.; PIRES, I. E. Resgate vegetativo de árvores de Anadenanthera macrocarpa. Cerne, v. 21, n. I, p. 83-89. 2015.

FRAGOSO, R. O.; ZUFFELLATO-RIBAS, K. C.; MACANHÃO, G.; STUEPP, C. A.; KOEHLER, H. S. Propagação vegetativa de Juniperus chinensis. Comunicata Scientiae, v. 6, n. 3, p. $307,2015$.

GLEASON, S. M.; WESTOBY, M.; JANSEN, S.; CHOAT, B.; HACKE, U. G.; PRATT, R. B.; COCHARD, H. Weak tradeoff between xylem safety and xylem specific hydraulic efficiency across the world's woody plant species. New Phytologist, v. 209, n. I, p. I23-136, 2016. 
GORDON, D.; ROSATI, A.; DAMIANO, C.; DEJONG, T. M. Seasonal effects of light exposure, temperature, trunk growth and plant carbohydrate status on the initiation and growth of epicormic shoots in Prunus persica. The Journal of Horticultural Science and Biotechnology, v. 8I, p. $421-428,2006$.

MASON, M. G.; ROSS J. J.; BABST B. A.; WIENCLAW B. N.; BEVERIDGE C. A. Sugar demand, not auxin, is the initial regulator of apical dominance. Proceedings of the National Academy of Sciences, v. II I, p. 6092-6097, 2014.

MEI, L.; XIONG, Y.; GU, J.; WANG, Z.; GUO, D. Whole-tree dynamics of non-structural carbohydrate and nitrogen pools across different seasons and in response to girdling in two temperate trees. Oecologia, v. 177, n. 2, p. 333$344,2015$.

MEIER, A. R.; SAUNDERS, M. R.; MICHLER, C. H. Epicormic buds in trees: a review of bud establishment, development and dormancy release. Tree Physiology, v. 32, n. 5, p. 565$584,2012$.

NICOLINI, E.; CHANSON B.; BONNES, F. Stem growth and epicormic branch formation in understorey beech trees (Fagus sylvatica L.). Annals of Botany, v. 87, p. 737-750, 200I.

OLIVEIRA, L. S.; XAVIER, A.; DIAS, P. C.; CORREIA, A. C. G.; BORGES, S. R.; TAKAHASHI, E. K.; PAIVA, H. N. Enraizamento de miniestacas e microestacas de clones de Eucalyptus urophylla $\times E$. globulus e de Eucalyptus grandis $\times E$. globulus. Scientia Forestalis, v. 40, n. 96, p. 507-5I6, 2012.

OSTERC, G.; STAMPAR, F. Differences in endo/exogenous auxin profile in cuttings of different physiological ages. Journal of Plant Physiology, v. I68, n. I7, p. 2088-2092, 20 I I.

PEREIRA, M. O.; WENDLING, I.; NOGUEIRA, A. C.; KALIL FILHO, A. N.; NAVROSKI, M. Resgate vegetativo e propagação de cedro australiano por estaquia. Pesquisa Agropecuária brasileira, v. 50, n. 4, p. 282-289, 2015.

RASMUSSEN, H.; VEIERSKOV, B.; HANSEN-MOLLER, J.; NORBAEK, R. 'Lateral control': phytohormone relations in the conifer treetop and the short-and long-term effects of bud excision in Abies nordmanniana. Journal of Plant Growth Regulation, v. 29, p. 268-279, 2010.

RASMUSSEN, A.; HOSSEINI, S. A.; HAJIREZAEI, M. R.; DRUEGE, U.; GEELEN, D. Adventitious rooting declines with the vegetative to reproductive switch and involves a changed auxin homeostasis. Journal of Experimental Botany, v. 66, n. 5, p. 1437-I452, 2015.

REIS, E. R.; LÚCIO, A. D. C.; FORTES, F. O.; LOPES, S. J.; DA SILVEIRA, B. D. Período de permanência de mudas de Eucalyptus grandis em viveiro baseado em parâmetros morfológicos. Revista Árvore, v. 32, n. 5, p. 809-8I4, 2008.
RICKLI, H. C.; BONA, C.; WENDLING, I.; KOEHLER, H. S.; ZUFFELLATO-RIBAS, K. C. Origem de brotações epicórmicas e aplicação de ácido indolbutirico no enraizamento de estacas de Vochysia bifalcata Warm. Ciência Florestal, v. 25, n. 2, p. 385-393, 2015.

ROSADO, A. M.; ROSADO, T. B.; ALVES, A. A.; LAVIOLA, B. G.; BHERING, L. L. Seleção simultânea de clones de eucalipto de acordo com produtividade, estabilidade e adaptabilidade. Pesquisa Agropecuária Brasileira, v. 47, n. 7, p. 964-97I, 2012.

SANTIN, D.; WENDLING, I.; BENEDETTI, E. L.; BRONDANI, G. E.; REISSMANN, D. M.; ROVEDA, L. F. Poda e anelamento em erva-mate (Ilex paraguariensis) visando à indução de brotações basais. Pesquisa Florestal Brasileira, Colombo, n. 56, p. 97-104, 2008.

SANTOS, H. G.; JACOMINE, P. K. T.; ANJOS, L. H. C.; OLIVEIRA, V. A.; OLIVEIRA, J. B.; COELHO, M. R.; LUMBRERAS, J. F.; CUNHA, T. J. F. (Ed.). Sistema brasileiro de classificação de solos. 2.ed. Rio de Janeiro: Embrapa Solos, 2006. 306p.

SOUZA, V. C.; LORENZI H. Botânica Sistemática Guia ilustrado para identificação das famílias de Fanerógamas nativas e exóticas no Brasil, baseado em APG II. Nova Odessa, SP, 3 ed. 2005, 768 p.

SOUZA, A. M.; CARVALHO, D.; ALMEIDA VIEIRA, F.; NASCIMENTO, L. H.; LIMA, D. C. Estrutura genética e espacial de populações naturais de Calophyllum brasiliense Camb. em mata de galeria. Cerne, v. 13, n. 3, p. 239-247, 2007.

STUEPP, C. A.; ZUFFELLATO-RIBAS, K. C.; WENDLING, I.; KOEHLER, H. S.; BONA C. Vegetative propagation of mature dragon trees through epicormic shoots. Revista Bosque, v. 35, n. 3, p. 333-34I, 2014.

STUEPP, C. A.; BITENCOURT, J.; WENDLING, I.; KOEHLER, H. S.; ZUFFELLATO-RIBAS, K. C. Propagação de erva-mate utilizando brotações de anelamento e decepa em matrizes de duas idades. Cerne, v. 2 I, n. 4, p. 519-526, 2015 a.

STUEPP, C. A.;WENDLING, I.; KOEHLER, H. S.; ZUFFELLATO-RIBAS, K. C. Rooting cuttings from epicormic shoots of Paulownia fortunei var. mikado adult trees. Ciência Florestal, v. 25, n. 3, p. 667-677, 20 I5b.

STUEPP, C. A.; BITENCOURT, J.; WENDLING, I.; KOEHLER, H. S.; ZUFFELLATO-RIBAS, K. C. Indução de brotações epicórmicas por meio de anelamento e decepa em ervamate. Ciência Florestal, v. 26, n. 3, p. I-14, 2016.

VAN DEN ENDE, W. Sugars take a central position in plant growth, development and, stress responses. A focus on apical dominance. Frontiers in Plant Science, v. 5, p. 313, 2014.

WAN, X. C.; LANDHÄUSSER S. M.; LIEFFERS V. J.; ZWIAZEK J. J. Signals controlling root suckering and adventitious shoot formation in aspen (Populus tremuloides). Tree Physiology, v. 26, p. 68I-687, 2006. 
WENDLING, I.; DUTRA, L. F.; HOFFMANN, H. A.; BETTIO, G.; HANSEL, F. Indução de brotações epicórmicas ortotrópicas para a propagação vegetativa de árvores adultas de Araucaria angustifolia. Agronomía Costarricense, v. 33, n. 2, p. 309-319, 2009.

WENDLING, I., BRONDANI G. E.; BIASSIO, A.; DUTRA, L. F. Vegetative propagation of adult llex paraguariensis trees through epicormic shoots. Acta Scientiarum. Agronomy, v. 35, n. I, p. II7-I25, 2013.
WENDLING, I.; TRUEMAN, S. J.; XAVIER, A. Maturation and related aspects in clonal forestry-Part I: concepts, regulation and consequences of phase change. New Forests, v. 45, n. 4, p. 449-47I, 2014.

WENDLING, I.; WARBURTON, P. M.; TRUEMAN, S. Maturation in Corymbia torelliana $\times$ C. citriodora stock plants: effects of pruning height on shoot production, adventitious rooting capacity, stem anatomy, and auxin and abscisic acid concentrations. Forests, v. 6, p. 3763-3778, 2015. 